\title{
"They Come from Chaos:" Considering the Power of Stories in Home-School Relationships
}

\author{
Kristin Lyn Whyte \\ Northwestern University \\ United States
}

\begin{abstract}
Complex depictions of home-school relationships examine the often-present gap between teacher perceptions and the lived experiences of families. One way to address this gap in understanding is by constructing narratives that detail the nuances of families' involvement, countering potential misperceptions and narrow views. In addition to using tools such as counter-narrative to speak back to deficit-laden stories told about marginalized families, researchers must also attempt to deeply understand all stories in order to think through what teachers' stories mean for how they understand their work. Thus, this paper presents a case study of a Head Start prekindergarten teacher that shows how her stories about families relate to her identity as a Head Start teacher. The stories show how power, stereotypes, and perceptions of families relate to her ideas about home-school relationships. Lessons learned from her stories ask educators to consider who is responsible for creating chaotic images of families' lives and what impact do stories characterized by chaos have when they are the ones told about families who live in poverty.
\end{abstract}

Keywords: Home-school relations, early childhood education, qualitative methods, figured worlds

I guess one of the biggest things, especially working with Head Start, when they talked about if they lived in mess, disorder, and clutter they will create disorder. And I always, we always talked about, especially with the children at Head Start, where if they're having issues in the classroom - sometimes, they live in chaos at home, so when they come to school they create chaos because that's what they're used to, that's what they 
"They Come from Chaos:" Considering the Power of Stories

know. And so the behavior's not really their fault, it's because they're just creating what they know. (Princess, class discussion, 3/6/2013)

Princess ${ }^{i}$ loves telling a good story. When I began looking across the kinds of stories Princess tells I was reminded of Chimamanda Ngozi Adichie's highly praised 2009 TED Talk, The Danger of a Single Story. Her lecture resonated with many as a call to better understand the lived experiences of other people. In her discussion of the power in stories she wisely pointed out, "[t]he single story creates stereotypes, and the problem with stereotypes is not that they are untrue, but that they are incomplete. They make one story become the only story." This paper is inspired by Adichie's ideas about the impact of a single story and, accordingly, I look at the stories that seem the most salient to Princess' perceptions of the Head Start families she works with. As I think through how Princess speaks about families, I consider what the prominent constructs present in Princess' stories mean for her identity as a Head Start teacher. I also explore how she contributes to her own figured world (Holland, Skinner, Lachicotte, \& Cain, 1998) of home-school relationships and how this relates to the idea of a single storyline about families. In doing so I address the questions: How does a teacher understand the families she works with? How do a teacher's stories contribute to her identity development and her figured world of home-school relationships? How do the stories a teacher tells about families relate to her understandings of home-school relationships?

\section{Perceptions \& Identity Development}

\section{Perception, Power and Complexity in Home-School Relationships}

Relationships between teachers, families, children, schools, and communities are deeply complex. Nuanced descriptions and critiques of home-school relationships that honor their complexity often draw attention to the relationships between teachers' perceptions and the lived experiences of families. Teachers' perceptions of families are constructed within their experiences and sociocultural-historical contexts (Lightfoot, 2003), connecting perceptions to existing power dynamics (Lareau, 2000; Moll, 2014). How these perceptions are constructed and expressed influence home-school relationships (Holland, et al., 1998).

Power shapes teachers and families' encounters with each other. Both teachers and families approach their encounters with preconceived notions about how their roles are defined in relation to each other. The lines defining these relationships are developed within the inequities inherent in our schooling system, "distorting and confusing the proximal spaces where the dialogues between parents and teachers occur" (Lightfoot, 2003, p. 144). For instance, how are families and teachers supposed to reconcile schools being both the great equalizer and tools of social reproduction (Lightfoot, 2003)? Schools have often reproduced race and class-based inequities, which impacts families' relationships with schools (Anyon, 1980; Diamond \& Gomez, 2004; Doucet, 2008; Lareau, 2000). Such inequities can be exacerbated, as teachers often claim to desire collaborative relationships with families, while expecting deferment to school-sanctioned, narrowly defined involvement practices (Cooper, 2009; Lareau, 2000). In order to understand how home-school relationships work, teachers need to recognize that they are actors within these contradictory systems and thus "are both bridge builders and gatekeepers... engaged in the dialectic of forging of connections and maintaining boundaries with parents" (Lightfoot, 2003, p.72).

Complex depictions of home-school relationships also examine the often-present gap between teacher perceptions and the lived experiences of families. One way to address this gap 
in understanding is by constructing narratives that detail the nuances of families' involvement, countering potential misperceptions and narrow views (Compton-Lilly, 2000, 2009; Doucet, 2008, 2011; Greene, 2013). Counternarratives are meant to speak back to the deficit-laden depictions of low-income minority families that "distort our perceptions of families and children" (Greene, 2013, p. 8). Such stories demonstrate the complexity of people's everyday lives while simultaneously offering ideas about the roles that experience, culture, and social context play in how educators and families make sense of their relationships. In addition to a need for counternarratives, researchers must also attempt to deeply understand the stories told about families. For counter-narratives to truly open the eyes of teachers to alternate possibilities, it is important to think through what teachers' stories mean for how they understand their work.

\section{A Sociocultural-Historical Look at Head Start Identity Development}

In order to more deeply understand the connections between Princess' stories and her understandings of home-school relationships, I use Holland and her colleagues' (1998) sociocultural-historical conceptualization of identity, Identity in Practice. This theory details how a person's identities are actively constructed through a combination of their daily experiences along with the contributions of their social, historical, and cultural contexts. Here identities are dialogic in nature - people continually actively construct and are constructed by their identities and everyday experiences. In this theory, identity construction has to do with both an individual's agency and being an inextricably social and heuristic process in which people try out different ways of being. Consequently, Holland and her colleagues do not seek to present "identity" as a singular, cohesive entity, instead they "conceive persons as composites of many contradictory self-understandings and identities" (p. 8).

Identity in Practice contains contexts of identity, two of which are particularly relevant here: figured worlds and authoring. Figured worlds are theoretical spaces in which people, along with their multiple identities, come together to actively participate in communities. Authoring has to do with how people draw from and respond to the messages coming from their cultural, historical, and social constructs and experiences to create their identities. Figured worlds and authoring are connected. How people contribute to the characteristics of figured worlds is based on how they respond to multiple discourses, power, and cultural artifacts in their daily actions. At the same time people are creating the nature of any given figure world, a figured world shapes people's understandings and how they author their identities. As people participate in figured worlds they use and construct tools that shape their identities, and in doing so create narrativized identities particular to the community they participate in.

These concepts about identity frame my thinking about Princess' stories and understandings of home-school relationships. The stories she tells about families act as both the messages being taken in and the telling of them as a response. Thus, the stories are a part of how she constructs her identity in relation to her perceptions of families. Additionally, they contribute to the nature of the figured world of home-school relationships Princess, her colleagues, and families all participate in.

\section{Method}

\section{Research Design}

This is a single, instrumental case study exploring the particulars of one teacher's understandings of home-school relationships (Dyson \& Genishi, 2005; Stake, 1995). It is part of 
"They Come from Chaos:" Considering the Power of Stories

a larger research project funded by the National Science Foundation, ${ }^{\text {ii }}$ the 4-year-old Kindergarten Professional Development (4KPD) project. The prekindergarten (preK) teachers who joined the 4KPD project enrolled in four 3-credit classes through the local university that took place over the span of two years-I was an instructor for three of the courses. The classes were conceptualized as a hybrid of graduate-level coursework and professional development. Classes were held weekly for $2 \frac{1}{2}$ hours a session at a public elementary school. The content of the 4KPD classes focused on developmentally and culturally responsive mathematics teaching based on Funds of Knowledge (FoK) framework (Moll, Amanti, Neff, \& Gonzalez, et al., 1992). Three cohorts of teachers participated in the project, including Princess.

Stake (1995) points out that often a case does not feel like a choice and soon after class began I realized I hoped Princess would work with me. I think of Princess as a data-rich participant (Patton, 2002). She consistently participated in class discussions. Often she sarcastically interjected her opinion while walking a fine line of what would be considered appropriate class behavior. ${ }^{\text {iii }}$ In her class contributions I felt like I could see her early childhood knowledge and excitement for her work, sparking my curiosity about her practice. Further, Princess is a Head Start teacher, which is an organization with a particular approach to homeschool relationships (Beatty, 2012) that I thought would offer an interesting contrast to the information being presented in the 4KPD project. I approached her about the case study a month into the first course and she readily agreed.

\section{Data Collection \& Analysis}

I collected data from September 2012 to December 2013. The data contain information about Princess' current practices, current professional development experiences, childhood experiences, her teacher training, the Head Start program she works in, and the neighborhood the Head Start center serves. The data are in the form of participant observations of her preK classroom, semi-structured ${ }^{\text {iv }}$ interviews (Seidman, 2006; Spradley, 1979), group discussions and written documents from the professional development courses, and written documents from the Head Start center. See Table 1 for detailed description of data collection. During participant observations I took ethnographic field notes, detailing thick descriptions of Princess' practices (Emerson, Fretz, \& Shaw, 2010; Stake, 1995). Participants and locations have pseudonyms. Princess chose her pseudonym, and I created the rest. Interviews and group discussions were audio-recorded, transcribed, and cleaned.

Table 1. Data Sources \& Collection

\begin{tabular}{|l|l|}
\hline \multicolumn{1}{|c|}{ Data Type \& Setting } & \multicolumn{1}{|c|}{ Frequency/Duration } \\
\hline Semi-structured interviews & $\begin{array}{l}\text { March 14, 2013: 2 + hours; April 11, 2013: 3.5 + hours; } \\
\text { June 21, 2013: 3+ hours; December 17, 2013: 2 hours }\end{array}$ \\
\hline $\begin{array}{l}\text { Classroom observations - Princess' } \\
\text { a.m. session }\end{array}$ & $\begin{array}{l}\text { Bi-monthly starting mid-January 2013. Ending with the } \\
2013 \text { school year. Total number: 11 sessions, 3+ hours } \\
\text { each }\end{array}$ \\
\hline $\begin{array}{l}\text { Family events (explicitly for } \\
\text { Princess' classroom) }\end{array}$ & $\begin{array}{l}\text { February (2013) Family Night } \\
\text { April (2013) Family Night } \\
\text { Jome visits/conference } \\
\text { observations }\end{array}$ \\
\hline Field trip observation & 3 home visits on June 4, 2013 \\
\hline
\end{tabular}

ISSN 2325-638 
Kristin Lyn Whyte

\begin{tabular}{|l|l|}
\hline 4KPD small group discussions & $\begin{array}{l}\text { There was a range of 1-4 small group discussions on } \\
\text { any given class night. Total: 53 group discussions. }\end{array}$ \\
\hline $\begin{array}{l}\text { 4KPD coursework (related to } \\
\text { home/school relationships) }\end{array}$ & $\begin{array}{l}\text { 7 individual assignments (3 FoK Reflection } \\
\text { Assignments; Assessment Assignment; Learning Story; } \\
\text { Home Visit Reflection; Family Math Night Write-Up) }\end{array}$ \\
\hline $\begin{array}{l}\text { Communication documents } \\
\text { (information that travels from } \\
\text { school to home) }\end{array}$ & $\begin{array}{l}\text { Ongoing from January (2013) through end of the } \\
\text { school year (June). }\end{array}$ \\
\hline Journal & $\begin{array}{l}\text { I kept a journal on an as-needed basis. I wrote in it } \\
\text { most weeks after class and after any other discussions } \\
\text { or contact with Princess. }\end{array}$ \\
\hline
\end{tabular}

I entered data into NVivo, with the exception of the communication documents. I wrote memos about both emerging analytic ideas and methods (Richards, 2009) throughout data analysis. I used a combination of emergent and deductive coding. Along with coding, I was continually reading, writing, and then coding further, creating a recursive data analysis process (Patton, 2002; Richards, 2009). I developed initial deductive codes from both Holland and her colleagues' (1998) contexts of identity and analysis of memos. I looked across coded data and created themes, which were used to drive further data analysis. I explored themes in relation to Holland and her colleagues' (1998) identity in practice. Triangulation was addressed as I looked across multiple data sources when making assertions (Creswell, 2007; Patton, 2002; Stake, 1995). This particular paper discusses one set of findings from the case study: the connections between Princess' stories about families, her identity development as a Head Start teacher, and her understandings of home-school relationships.

\section{About Princess}

Before delving into the findings, I am going to tell you a little about Princess and my role in her classroom. Princess is a 35-year-old white woman who has been teaching for Head Start for 12 years. ${ }^{v}$ She grew up in Milford, a small city in the Midwest. ${ }^{\text {vi }}$ She moved to Bellevue, a small city about $2 \frac{1}{2}$ hours from her hometown for college. Here she earned a bachelor's degree in elementary education with a minor in early childhood education. When Princess first graduated from college she looked for jobs across the state. There were a couple different jobs in Oscarburg, ${ }^{\text {vii }}$ and a Head Start position was the first one she was offered so she decided to give it a try. Princess worked in a preschool classroom for 1 year and then with toddlers at a different site. While working with toddlers, she returned to the university at Bellevue for her master's work. She enrolled in a program tailored for practicing professionals across the state. Her final paper was based on an action research project she conducted using sign language with toddlers.

In 2011 Oscarburg began offering preK in the public schools. In partnership with Oscarburg's school district, in addition to the public schools, community-based early childhood sites also operated public preK. Princess' teaching degree made her eligible for teaching preK and she decided to move to a preK classroom at the Lincoln Ave Head Start.

As a Head Start teacher, Princess is part of a team of staff who work with the children in her classroom and their families. Princess has four people on her team-Marisol, Beatrice, Mariella, and Mike. Marisol is the family outreach worker assigned to Princess' classroom. Beatrice and Mariella are assistant teachers and Mike is the bus driver for Princess' classroom. 
While Beatrice and Mariella have the most consistent contact with families because they ride with the children on the bus each day, Marisol is the person who connects families with services and acts as a liaison between Princess and families. The team is in constant communication with each other, including Marisol and Princess, although the majority of their day is spent in different spaces. They share an office, go on home visits together, plan family events, and keep each other informed about families' needs and services. They talk at the beginning and end of each day, Marisol often stops by to share information with Princess during the day, and they leave each other sticky notes on the door by the phone throughout the day.

I felt welcome in Princess and her staff's classroom. When I first started classroom observations Princess and I had known each other from the 4KPD classes for about 5 months. It felt easy to blend into the classroom. Most often I sat quietly observing and taking notes on my laptop, although I would briefly take a more active role when an extra set of hands seemed helpful. I also made a point of making time to play with the children each visit. For each observation I arrived before the children. In addition to taking notes, I would help Princess get her classroom ready for the day viii and at the same time we would chat. We talked about things that were happening with children in her classroom and their families, what we did over the weekend, and topics from the 4KPD classes. Often I felt like I had more of an "insider status" in the classroom. The staff knew I used to be a prekindergarten teacher ${ }^{\text {ix }}$ and I think this, along with knowing Princess for some time beforehand, contributed to how welcoming and open they were. At the same time, I was the researcher and teacher from the university. They would ask questions about the content of the research and offer me information about their work that they anticipated I would find interesting. These differing roles were dynamic, in a constant state of negotiation. For me, feeling like I had an insider status at times continues to impact the research. I have a great amount of respect for Princess, think highly of her commitment to children and many of her classroom practices. Although this makes critiquing her understandings about home-school relationships difficult, it is important to recognize the complex nature of working with families and that good teachers can frame families in problematic ways.

\section{Princess the Storyteller ${ }^{x}$}

Princess has plenty of stories to tell about the families she works with. Some of the stories have to do with learning about families' home practices that she considers positive. These stories often contain a feeling of warmth and show how she really enjoys working with families. For instance, after conducting a home visit with a family, she happily shared that she learned about their board game night. She also occasionally uses stories to combat stereotypes about poverty-stricken neighborhoods and the families living in them. Once, when Princess' colleagues were talking about how unsafe a neighborhood was, she was the first to point out that good people live there. She did so by telling the class a short story about who she would meet while going for walks with her Head Start classroom around the neighborhood.

These stories, however, are not the ones Princess typically tells. The stories with more of a positive feel are often brief without much of a narrative flow, contain minimal detail, and occur infrequently in comparison to her stories that have more of an outlandish, rough, or disparaging feel to them. Princess' stories are usually depictions of a funny or unusual thing that happened, a home practice she sees as needing changing, a difficult and intense encounter with a family, or a story showing how crime and abuse are a part of children's lives. These stories reinforce a 
statement she repeatedly expresses about children: "You learn that they come from chaos, so they're going to create chaos because that's all they know" (Princess, Interview 1, 3/14/2013).

\section{Story 1: "But She's Got to Brush it off" \& Considering Power in Princess' Relationships with Families}

The families I work with are quite diverse. Most of them, this year we haven't had many, but most of the time we get a lot that you wonder if they've had issues with teachers in the past or schools with the past because they're very defensive. You get some parents that with every little thing they make a big deal, "My child said so-and-so did this or said this." You know, and just make a huge deal out of it. Like last year we had a parent who there were some mental issues and this was her fourth child who went through Head Start. I remembered it was a parent that when I was in the toddler room who had called up one day and said she had wanted me to patch her through to the bus. And I told her I can't do that from this phone. The only place that can do that is the main office. And she said, "Who is this, who are you, what is your name?" And I told her and she said, "You're a fucking bitch. dadadadada." I said, "I'm not going to let you talk to me that way." And before I could hang up on her, she hung up on me. I remembered, "you know what, wait a sec, I think that was the lady who used to call and scream at people - I think that's a family we have here now." One time she got upset with Marisol and just, "You fucking bitch, dadadadada." But she's got to brush it off because in the next few days she's going to call me to go over to the food pantry because she's got to go to the food pantry. It's kind of nice for me because I can say, "Go talk to Marisol." (Princess, Interview 1, $3 / 14 / 2013)$

Princess told this story in response to the first interview question that explicitly asked her about families, "Tell me about the families you work with." Although the story comes off as intense, Princess did not sound serious when she was telling it. She seemed mildly exasperated and resigned when talking about the defensive nature of families. She was laughing when she called the families diverse and said the parent cussed at her. She appeared bemused at the idea of already knowing about the cussing woman from the center she used to work at. And when she mentioned the food pantry at the end she sounded like she was simply sharing a lesson about "not biting the hand that feeds you."

Princess' moral at the end of the story draws attention to the idea that power plays a role in her relationships with families. Power is present in spaces, interactions, and structures that people organize around (Holland, et al., 1998; Lightfoot, 2003; Moll, 2014). It exists in the "dissonance between our values, rhetoric, and actions" (Lightfoot, 2003, p.114), complicating relationships between schools, teachers, and families as teachers and families attempt to collaborate within the reality that schools often fail marginalized families. As Princess both responds and contributes to ever-present power structures, it becomes a part of how she defines her identities in home-school relationships (Holland, et al., 1998).

Head Start functions as both a gatekeeper and bridge to multiple services. Head Start can be likened to a bridge because it connects families to services. For instance, families can get assistance with legal and housing matters, high school equivalency and English as second language classes, and Head Start can also help with getting access to clothing, medical care, and food (Zigler \& Styfco, 2010). At the same time, Head Start is a gatekeeper in the sense that it is between families and services, controlling how services are accessed. Consider how Princess 
talks about the food pantry in relation to the confrontational parent. When Princess says the parent needs to "brush it off' when she wants access to the food pantry she shows that she and Head Start control access to this service.

Although Princess tends to tell and refer to these kinds of conflict-ridden stories, she also has a strong desire to build partnerships with families. Power, however, can complicate the best of intentions. Lightfoot (2003) noted, 'both parents and teachers have a sense of territoriality that shape their encounters, a map in their minds whose lines define their appropriate roles and range of their authority" (p. 50). When Princess talks about developing relationships with families, words like "turf," "breakdown," "willing," "equal," "levels," and "sharing" often come up. The language itself sheds a light on how power is a part of defining her home-school relationships.

Princess recognizes that as a Head Start teacher she tends to retain power in her relationships with families. She thinks home visits can be a good tool to help shift power imbalances in a way that creates more equality in home-school relationships. Princess has noticed a power shift while conducting home visits - "when you're on their turf, they open up more," that families seem to think, "[o]kay, you're on our level now ... that they're more comfortable in their home setting and are more willing to share" (Class Discussion, 9/12/2012). She thinks that being in families' homes creates closeness simply from being in the home, "Sometimes you're just sitting on the living room couch. So I feel like it's more personable. It makes them feel like they're more of equals" (Princess, Interview 1, 3/14/2013). Princess recognizes that there are different "turfs" and that these spaces hold power. She hopes that interacting with families outside of school will make them feel more like actual partners. It is clear that Princess feels a need to shift power relations with families, but to what end is more complicated.

Princess thinks of developing partnerships with families that are characterized by a general equality as being an important part of her work. She repeatedly speaks about wanting parents "to feel like equals" (Princess, Interview 3,6/21/201), but she does not explicitly talk about what equal means in practice. Instead she talks about the results of having equal relationships with families. "The more equal they feel the relationship is, the more willing they may become to do different things or implement things with their child, or be more honest about what they need help with" (Princess, Interview 3, 6/21/2013). Instead of truly sharing power, this definition of a family-teacher relationship is more akin to what Lareau (2000) noticed in her study of home-school relationships, "a partnership implies a relationship between equals where power and control is evenly distributed ... Instead, [teachers] wanted parents to defer to them and to their decisions in the classroom" (p. 35). To an extent, Princess recognizes that she has more power than families, but she is not aware that her picture of an ideal equal partnership still keeps power in her hands.

Princess' desire to establish equal partnerships conflicts with why she wants them established. She tries to create positive relationships with families so it is easier to have them follow through on school requests. For Princess, "equal" is more an equal distribution of families participating in activities and developing demeanors that support school goals. She does not seem to notice the conflict present in wanting families to acquiesce to school requests and developing "equal relationships." Teachers and schools control what counts as family engagement and their definitions are often narrow (Adil, 2006; Cooper, 2009). A teacher-family relationship cannot be an equal if families have little control over how it functions. That said, Princess does recognize her conversations with families, even when in their homes, are about school topics, "At the end of all of my home visits I'll ask if are there any other questions, but it's 
more concerning the classroom" (Class Discussion, 10/23/2012). Princess knows that when she asks families if they have any questions there is a shared expectation that their questions are about the classroom and most likely in response to topics she introduced during the home visit conference.

Power issues are also present when Princess talks about difficulties forming partnerships with families. She finds that some families can be wary, avoiding or refusing the services Head Start offers. She often attributes this to families seeing school as separate from home and at times being too prideful to accept services.

I just think there's a cycle. You grew up in a family that didn't really trust the school system, and you didn't have positive experiences, and that child grows up, and it could change, but it's the same old, you know, school and home life are separate. It's just a cycle we try to break. We tell families, "This is what we can offer you," and some just won't. Like, with Joey's mom, she was hard to break down, and there was one time where like, he had a dentist appointment, and Marisol just happened to call and ask, "Do you need a ride?" And she said, "Oh, you can give me a ride? I was going to cancel it, because I was going to have to pay for a cab." You know, it's like, "We told you." So he ended up going and getting his dental appointment done when he might not have. Sometimes, they're just prideful and don't want to admit that they need the help.

(Princess, Interview 3, 6/21/2013)

Princess uses phrases such as "she was hard to break down" and "we told you" while she talks about Joey's mother not initially following through on the offer of a ride to the dentist. Her tone shows her frustration. It also leaves her sounding patronizing and shows how she has the power to deem particular Head Start involvement practices as worthwhile. Princess' assertions about families often show how power functions in home-school relationships. When she talks about getting Joey to the dentist, for example, it is easy to see the connection between power differentials and the conflation of teaching and parenting roles. Here power issues surface in a moment when Head Start is involved in children's overall health, showing how tensions can arise when school staff gain control over routines that are more traditionally left to families (Lightfoot, 1981).

Sometimes Princess thinks of particular Head Start practices as positive even when families do not want to take part in them. She thinks that families can feel like schools are prying, and she has families who have asked her, "Why do you care what I'm doing at home? In my family?" (Princess, Interview 3,6/21/2013). In these instances, Princess thinks families are being defensive, reflecting a view of separation between home and school.

I put the family's strengths in the developmental summary, when I was going over it with her at the end of the day. Then I just happened to catch her the next time she was in the building and said, "We need this signed." When I told her what I put in the family strengths section she said, "They don't need to know all that." So I told her, "Alright, I'll block it out when I get back." I was just trying to put down strengths of her family, but that's okay.... Some people are just private and think home and school are separate and no one should be in their business. (Princess, Interview 3,6/21/2013) 
"They Come from Chaos:" Considering the Power of Stories

Princess acknowledges that there are reasons some families think of home and school as separate, but believes families who do not respond to schools are not recognizing that "the better relationship we have, the better it is for your children and their education" (Princess, Interview 3, 6/21/2013). It is hard for her to see alternative interpretations for family involvement. For instance, in the example above she does not consider that telling a parent "we need this signed" is not the language of the equal partnerships and might make a parent wary. It is important to note that families actively make choices about their involvement. Sometimes this includes not being involved in school-sanctioned activities because they want to protect their children from an oppressive system (Doucet, 2011). Princess recognizes that families have had negative school experiences and therefore want to keep school and home separate. She, however, does not think this is a wise decision, as she does not see herself as part of an oppressive system. Princess thinks of Head Start very positively and believes the organization plays a crucial part in closing achievement gaps (Class Discussion, 9/11/2013). Thus, when a family chooses to not participate in Head Start-sanctioned activities, she focuses on convincing the family that such participation will benefit them without critically considering the system she is asking them to buy into.

Power \& chaos. How power issues surface shows some of the chaos Princess sees as characterizing families' lives. In the opening story Princess' description of a confrontational parent with mental health concerns who needs to "brush it off' so she can get access to the food pantry makes it is easy to see the chaos Princess ascribes to children's lives. Focusing in on how power is a part of how she understands home-school relationships provides a more complex picture. Instead of just seeing "chaos," more possibilities are created for why a parent might curse at a teacher or refuse to sign a form depicting her in a positive light. By considering why a parent might act chaotically, more possibilities are also created for what to do to further the relations hip.

\section{Story 2: "You May Have Been Right About That One" \& Princess' Assumptions about Families}

We had picture time, where there was a little girl in the afternoon whose dad had come in, and he wanted to pay for the pictures, and he pulled out a $\$ 100$ bill. He said, "You got change?" And I told him, "I do not have change, I work for Head Start, I'm a teacher." So he went to go get change, and Marisol made the comment, "We don't want your drug money," or something like that. So I said, "Marisol, you cannot assume that because he pulled out a $\$ 100$ bill, you know, that he's selling drugs. You know, maybe he was just working, he just cashed his check somewhere, because when you cash a check, they don't give you small bills all the time, unless you ask for them." And so, I really tried to think, "You can't just assume that." But it comes out - I had looked him up on CCAP, because she had told me that someone had asked, "Oh, why didn't your dad come to end of the year celebration?" She had said, "He's in jail." So I was just a little curious, you know, and looked up and, saw what his latest charge was and saw a whole bunch of stuff. So I looked in there and there's several arrests for possession of cocaine with intent to sell, so I had to go with, "Well, OK, Marisol, you may have been right about that one." But, but just trying not, and you know, to assume. There's times where I assume and I get to know the family and think, "Mmm, yeah, you don't know what I thought about you at the beginning." But I try not to. (Princess, Interview 3, 6/21/2013)

Princess's impetus for this story started by her acknowledging that teachers make assumptions about families and that this is something she wished did not happen. Except for the beginning 
when she jokes that she does not make enough money to have change for a $\$ 100$ bill, this story was told with less laughter and in a bit more of a matter-of-fact tone. Similar to the story above, it ends with a lesson. When Princess began this story it seemed as though she was going to make a point about the damaging nature of assumptions. Instead she told the story to show that sometimes assumptions turn out to be real possibilities.

Teachers make assumptions about families' lives, and often these assumptions are based on stereotypes (Compton-Lilly, 2009; Lightfoot, 1981). Compton-Lilly (2009) warned that assumptions and stereotypes prevent teachers from recognizing families' potential and strengths. She has asked educators to rethink "assumptions about students and their families" (p. 449) and confront discourses and practices that contribute to ways of thinking that disregard the complexity of families' lives (p.457). Lightfoot (1981) discussed the damaging nature of teachers' assumptions for Black families. She noted that "[d]espite the passionate and often unrealistic dreams of black parents, teachers continue to view them as uncaring, unsympathetic, and ignorant of the value of education for their children" (p.100). Lightfoot tied these detrimental teacher-held assumptions to families and teachers not understanding each other: " $[\mathrm{t}] \mathrm{he}$ dissonance between black parents and teachers, therefore, does not lie in the conflicting values attached to education but in the conflicting misperceptions they have of one another" (p.100). I kept these lessons about assumptions and stereotypes in mind as I looked at how assumptions connect to Princess' understandings of families' lives.

According to Princess, a part of her role as a Head Start teacher is to try to not assume things, especially stereotypical things, about families even if she is ready for these assumptions to be true. She often talks about how assumptions and stereotypes, terms she uses almost interchangeably, come up in her work. These discussions are often about relationships between existing stereotypes about race, socioeconomic status, and ability. When she brings this topic up it usually is done in four slightly varied veins: 1) the role stereotypes have played in her personal life, mostly citing when they are untrue; 2) while the children play they exhibit knowledge they have from outside of school about stereotypical topics; 3) the relationship between stereotypes, race, and family traditions, holidays, or celebrations; 4) Head Start families and children face stereotypes associated with their socioeconomic status.

During 4KPD class discussions with her colleagues, Princess makes a point to talk about the importance of not assigning traits to children based on their socioeconomic status.

But it's also stereotyped because, you know, all my families are low income, at risk. And you think, oh, there's such a knowledge gap, an achievement gap. I have this little girl that I had to check her birthday because she's even above those preK standards and I look, she's only three...but a lot of people think like oh, low income, at-risk children they're coming in with no skills. (Class discussion, 10/3/2012)

Princess is concerned with having high expectations for all children, "No matter their gender, race or ethnicity, or socio-economic status I believe that all my students can learn" (Math Autobiography Reflection Assignment). She shares cases of children who are counter examples of detrimental stereotypes. She takes pride in sharing these counter-examples. Her refusal to give credence to stereotypes that associate socioeconomic status, gender, ethnicity, and race with academic capability seems to be reserved for children and does not always extend to families.

In the story opening this section, Princess chided Marisol for the drug money comment. Then, however, she decided to find out more about the parent's potential criminal history, giving 
credence to stereotypes about low-income men of color. For Princess, his arrest record created a particular meaning for the $\$ 100$ bill, even though she really does not know where the money came from. There are numerous reasons why someone might carry a large bill or have an arrest record, but these alternate possibilities do not make their way into Princess' story.

More generally, Princess acknowledges that she works with an "at-risk" population and wants people to understand that some of the families and children successfully work on school academics. At the same time, she does think that working with families living in poverty presents particular challenges. While Princess was in college working on her teacher's certification she spent her final early childhood practicum experience student teaching at the campus childcare preschool. She uses this experience to illustrate her understanding of socioeconomic differences between families.

It seemed like there weren't as many challenging behaviors. You didn't have any of the at-risk children and anything that comes along with that. Children weren't dealing with mom going to jail last night and not having enough to eat at home and stuff like that. So parents could be more involved in their education. Where I think a lot of my parents want to be, but may not know how to be or they have to work so much that they struggle to have to feed them ... it seems that more prominent, well-off parent might have more education about child development or where others don't (Princess, Interview 1, $3 / 14 / 2013)$

Princess sees a connection between socioeconomic status and the kinds of knowledge and time families have. Families who live in poverty do have different demands on their lives that deserve attention (Berliner, 2006). Princess' ideas about how socioeconomic status influences a family's capabilities to support their children draws attention to the challenging task of both addressing families actual needs and not perpetuating stereotypes of poor families. It is important for teachers to really get to know and develop relationships with families so they see more than just narrow, assumption-laden characterizations of families.

Princess also talks about assumptions and stereotypes that have to do with race, ethnicity, and cultural practices. She repeatedly makes the point that just because a family is a certain race or ethnicity does not mean teachers can assume they know about their practices and traditions. She typically brings this up when talking about holiday celebrations, saying it would be wrong for a teacher to celebrate Kwanzaa just because she works with African American families. She thinks teachers need to talk to families and find out what traditions are important to them instead of making assumptions. Conversations about stereotypes and holidays feel easy for Princess to have. Talking about how particular families are involved based on race and ethnicity is much more difficult.

Princess repeatedly refers to stereotypes about Latino culture when describing parent involvement.

[C]ulturally, Latino families, from what I know, they kind of put teachers on a pedestal, which is kind of nice because they're like, "Ahhh." They teach their children to be much more respectful, I feel. I know that's not right, it's just a stereotype and it's not typical. It just feels they are more respectful, they way they are to the teacher. More respectful interacting with the teacher and listening to the teacher and respecting what we say, which is nice. You know, you don't want to just, respect should be earned, but I just feel like, I don't know. (Princess, Interview 1, 3/14/2013) 
She consistently speaks about Latino families in this manner, being respectful of teachers. Princess almost exclusively works with either Latino or African American families. Although she talked about Latino families openly from the beginning, she did not do the same for African American families. In fact, the contexts she brought up "Latino culture" in almost seemed to be making more of a point about African American families. It was not until the end of my time in her classroom that she more explicitly discussed some of her thoughts about African American families' involvement.

Well, it just, I can't even say it's stereotypical, because it, the Latino families seem more welcoming. Like the other families will welcome, but I don't know. Because it just seems some, stereotypically, some African American families are more, um, prideful. And they're more walled off and, "It's none of your business..." I also get the families that sit there and talk forever with me, but it seems like the more issues they've had with school the more walled-off they are. School - home - separate, my life is not your business. And that's just, I think, some of the personalities of the parents, but I don't know. I think it's, I want to say it's kind of stereotypically that way, but there's always the exceptions. Sometimes in my head, you know, it just seems that Latino families are more respectful of teachers. They hold you up on this pedestal and what you say goes, "You better listen to your teacher." Where African American families are more like that cartoon I showed you (see Figure 1 for cartoon), "Why is my child - " you know, coming and taking their child's side over the school's side. I don't know if it's because they don't want to be victimized. Or it's like, "How dare you, you're- " you know, if it's a cultural bias. "How dare you do this to my child?" and, "What problem do you have with us?" (Princess, Interview 3, 6/21/2013)

Princess' tends to feel it is a given that the Latino families start from a place of respect in how they approach her, but that this does not hold true for African American families. She thinks African American families tend to be defensive and not as connected to school. Princess thinks of Latino families as being more willing to work with her in terms of responding to her requests for involvement.

How Princess talks about families' and children's lives in comparison to her own childhood also shows how assumptions are tied to the conflation of race and class.

And I came from a small town, a primarily white town and you, well, I never knew that and a kid swears at me now and before I'd be like 'how dare you.' And now I see, or, I've learned how not to take it personally I guess. You learn to understand, that's what they hear at home so of course they're going to say that. (Princess, Interview 1,3/14/2013) 


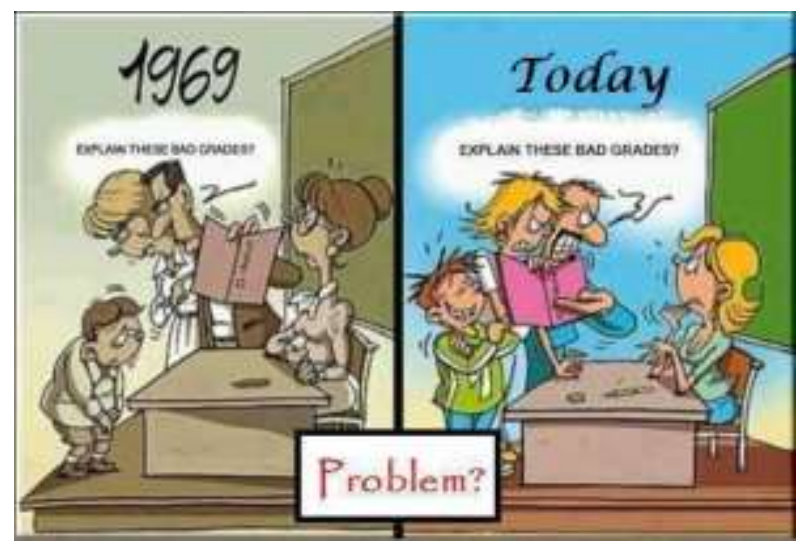

Figure 1. Cartoon Princess refers to when talking about differences between Latino and African American families.

This came up at a point during an interview when Princess was talking about her teacher preparation program. She thinks her teacher preparation program taught her a great deal about learning and development. She does not, however, feel she was effectively prepared for Head Start. She thinks she was prepared for, "campus childcare land," which Princess says was more about working with more "well-off" families (Princess, Interview 1, 3/14/2013). Princess thinks she was not prepared for children's difficult behaviors; behaviors she assumes come from their home lives.

Assumptions \& chaos. Stereotypes and assumptions about families are tied to how Princess sees chaos being present in families' lives. In addition to facing the reality of living in poverty, as Princess points out, all of her families face stereotypes because of their socioeconomic status. Although Princess tries to not give credence to stereotypes, it is clear from her stories she makes assumptions, most often race and class-based, about families' lives and that she sees assumptions as being at least partially based in reality. These assumptions contribute to creating chaotic depictions of families' lives. For instance, she assumes the parent with the $\$ 100$ is probably a drug dealer - even when he shows up to picture day, supporting the school and ready to purchase pictures of his child. She does focus on "positive stereotypes" of Latino families, but they too include assumptions and are connected to assumptions containing detrimental characterizations of African American families.

\section{Story 3: "You Could Have Just Got Dressed" \& A Glimpse into Families' Lives}

Sometimes, information gets lost, like today it was kind of funny. Diamond and Jada's mom had called me and told me they had pink eye and that they wouldn't be back until Friday. So I said "you're going to send them back whether or not they can see because you cannot handle those two by yourself." She just laughed and she told me, "If they're not back Friday, they'll definitely be back Tuesday." So I come in, walking in late today and usually I'm never there after 8:00 and there's dad in his bathrobe and jeans with his shower cap, sitting in my classroom with the two girls. One at each table, it was quiet and they were sitting there, in their chairs. I don't know if he made them sit in their chairs and he was sitting there between the tables on a chair. And I walk in and am, "Oh, hi." And he's sitting in his brown bathrobe, pants and his shoes. I said, "I'm sorry the bus didn't stop, mom said they weren't coming back until Friday." He said, "I know, I tried to chase the bus, but it's faster than I thought. You see how I'm dressed?" I sure do. He says, "I've been medicating them five times a day." And I'm sitting there thinking, "I don't 
know if you're supposed to be putting those eye drops in that often." He says, "I've been medicating their older sister, I've been medicating myself." I'm like, okay. And both the girls just sitting there as quiet as can be. Jada was sort slouched forward, and he's says, "Sit in that chair right." And then he left, and I told them "you guys can go read a book if you want" because they were just sitting there at the tables, and they both quickly got up. So Beatrice had them crossed out on the sheet and I told her, "If you don't pick a kid up don't cross them out because if they get walked in we still have to sign them in." She said, "Oh yeah, I thought so, but I was told they weren't coming." And I said, "Yeah, so was I." How's Beatrice going to know that they weren't going to come because I didn't leave a note, but Mike knew so. But oh my gosh, like that's what I wanted to walk into. And he said, "We've been in here since 7:50." I'm thinking, "In your bathrobe." I mean you could have just got dressed.

(Princess, Interview 1, 3/14/2013)

Princess' often gets little glimpses into families' lives. Sometimes Princess will mention something she learned about families' lives that shows how value is placed on typical middle class activities (Lareau, 2000): "Well there's times like I find out kids are taking soccer and karate ... they teach about respect," (Class Discussion, 10/3/2012). Most of the time, however, differing kinds and degrees of craziness or chaos characterize these glimpses, especially the ones that are talked about. The story above came out of a conversation about the bussing procedure. It seems to be mostly about information getting lost between parents and staff, but Princess tells it because it is funny. In this story there was miscommunication between both parents and Head Start staff and as a result, Princess got a glimpse into the craziness of a family's life.

Princess told this story with a lot of laughter. And there are plenty of funny things happening here - walking late into work to find a man in a bathrobe, jeans, no shirt, and a shower cap on; the three-year-old and four-year-old daughters sitting quietly and properly at separate tables; Dad exclaiming that he just chased after the bus in the bathrobe. From observing Princess interact with this family, I get the impression that they all get along really well and joke around with each other often. The moment where Princess jokes with Mom, "You know you cannot handle those two by yourself," could be seen as offensive, but it seems to be more reflective of her closeness with this family. Mom and Dad have both joked with Princess that the girls can be a lot to handle so they are going to ship them off to Princess so she can "deal" with them.

She often gets glimpses into families' lives during home visits. Sometimes these are positive peeks, but just as often she leaves home visits with feelings of understanding and relief after witnessing children's behavior. She often jokes about how after seeing a child at home, it is easier to understand difficult school behaviors, "Ahh, now I see why ... I'm like just to see how they are at home compared to school - I'm glad they're not like that at school" (Class Discussion, 10/23/2012).

Princess frequently brings up situations that show how families are dealing with abuse, drug use, or needs in terms of food, clothing, and housing. Sometimes she shares such moments to use as the context for stories about families.

He was adopted and he had fetal alcohol syndrome. His adopted mom was actually his great aunt. Anyways, we have a hat lady who came and made fleece hats like for all the kids and he wanted an all-pink one. He was so proud and so happy of it. One of his 
"They Come from Chaos:" Considering the Power of Stories

brothers took it away and threw it in the garbage that very day. Took it off his head and threw it in the garbage, and he was sad. His mom then like bought him some grey gloves with pink stripes on them so he was happy. But I felt so bad - he's so happy when he can be in a dress and wear pink. (Class discussion, 10/3/2012)

Here Princess provides a tiny bit of information about the little boy who loves his pink hat. His adoption and fetal alcohol syndrome offer a small amount of information about his life and is seemingly not connected to the point about gender expression. Sometimes Princess also shares this kind of information to make a greater point about why teachers should know about families' difficult situations. Princess thinks that learning particular things about a family's life can help teachers be more understanding in their work with both children and families.

Last year we had this dreaded family that we were glad it was the last child. They've had problems for years. Mom had meth issues and stuff like that, but knowing her background explained a lot why she was defensive about certain things that would happen in the classroom - like when her child got a bruise and she was just, "no one better be abusing my daughter," and you know I'm like she bumped into the playground, you know? But knowing that okay, Mom has this history of abuse made us more patient. (Class discussion, 10/3/2012)

Princess believes the more she knows about families' lives the easier it is to be sympathetic towards them, especially when there are tense or difficult encounters between families and teachers. Princess often learns about families' lives outside of school by talking with them during home visits and through other staff members. Despite the section on her parent/teacher conference form on "families' strengths," most of what Princess learns has to do with difficulties present in families' lives - most likely because Head Start tries to learn about these things so they can address families' multiple needs. This influences the kinds of things Princess learns about families, making most of the glimpses she gets connected to families more prominent needs.

Glimpses \& chaos. Learning about families' lives can benefit home-school relationships and teachers' work with children (Moll, Amanti, Gonzalez, \& Neff, 1992). At the same time, it is difficult and perhaps unreasonable for teachers and families to form close, deep relationships (Doucet, 2011) - it makes sense that teachers only get glimpses into families' lives. This does not, however, alleviate the problem with glimpses, which is that they only offer teachers a tiny bit of information. Glimpses make it easy for teachers to fill the gap between what they do and do not know about families with assumptions. For Princess, these glimpses are often emblematic of her idea that Head Start families live in chaos.

\section{Discussion \& Conclusion}

\section{Princess' Stories, Perception, and her Relationships with Families}

The stories Princess tells about families support her belief that sometimes the children she works with live in chaos. Whether it is blatant displays of power during chaotic moments or getting incomplete pictures of families' lives, making it easier to see them as chaotic, the idea of chaos is present throughout Princess' stories. The parents in the Princess' stories do chaotic things like running around with a bathrobe on, cussing out a teacher, have arrest records, and engage in inappropriate parenting techniques. The danger of her stories is the potential to create 
a single story - that families living in poverty live in chaos. For Princess, children's chaotic lives can make working with them at school challenging at times. She sees these kinds of situations as distinguishing Head Start teachers from other teachers: "I think it takes a special, I just don't think every teacher can work at Head Start - I really don't. Because of the population you work with and the amount of at-risk challenging behaviors. Just because the populations we work with" (Princess, Interview 1, 3/14/2013).

At the same time, it is important to point out that Princess' stories are events that happened and raise serious concerns, which is one reason thinking about them is complicated. No, most of time parents should not cuss at teachers, and yes, teachers should be able to work collaboratively with families on supporting a child's healthy physical and emotional development. Regardless, teachers need to be thoughtful about how they portray such exceptional cases, about what this means for how families are portrayed in general, and that stories about families influence relationships between home and school (Greene, 2013).

Princess' stories connect through more than just chaos. The constructs each story highlights also connect. For example, Princess' position as a Head Start teacher brings her into families' homes and at times gives her greater access to information about families' lives. Rather than learning a full set of information, she tends to learn bits and pieces. These pieces of information meld with her assumptions about families. She uses her knowledge of early childhood education practices to make decisions about how to understand and respond to assumptions about families. Overshadowing all of this is power - the power of her and Head Start's roles, the use of power when interacting families, and the power that lies in taking part in perpetuating a single story.

\section{Princess Stories and Developing a Head Start Teacher Identity}

Princess' stories are connected to how she defines her role in home-school relationships, her identity as a Head Start teacher, and her figured world of home-school relationships (Holland, et al., 1998). A part of how people form their identities has to do with how they respond to their experiences. Holland and her colleagues discuss the idea of narrativized identities developing within figured worlds, meaning people develop narratives about themselves within particular worlds as they participate in them. Figured worlds contain tools of identity that, when used, are a part of identity construction. For instance, Princess' stories and the idea of "chaos" could both be conceived of as tools of identity. As she uses these tools by retelling stories and speaking about chaos she constructs what it means to be a Head Start teacher and a Head Start family in her figured world of home-school relationships. I think of this as the development of her Head Start teacher identity rather than just a teacher identity for two reasons. She has only worked as a teacher in Head Start and, more importantly, she thinks of Head Start as lending itself to a particular kind of teaching that is characterized by chaotic lives and difficult behaviors.

In the first story when the parent cussed at Princess and she said she was not going to be spoken to like that, in a sense, she becomes a teacher who stands up for herself even in intimidating situations. When she starts talking about the mother needing Head Start to get access to food she becomes a teacher who is aware of her power position as well as defensive and patronizing to parents. In the second story when she responds to Marisol she is a defender of parents, and when she checks to see if the father has a criminal record she justifies making assumptions, defending her right to assume and stereotype. In the third story, when she thought about how Jada and Diamond's dad should not be showing up to school in his bathrobe she 
becomes a teacher with particular behavior expectations of families. What is the significance of Princess choosing to tell these particular stories? It is not just the actual experiences that form her perceptions and Head Start teacher identity; the act of telling the stories must also be considered. As she tells particular stories and not others, Princess takes an active role in both her identity formation and who families are in her figured world. The stories Princess experienced that she chooses to retell create the single story about families having chaotic lives.

These stories are a part of Princess' figured world of home-school relationships (Holland, et al., 1998). Within figured worlds, people "are not just products of our culture, not just respondents to the situation, but also critically appropriators of artifacts that we and others produce" (Holland, et al., 1998, p. 17). As parts of these stories contribute to the authoring of Princess' Head Start teacher identity, they influence her thoughts and practices and become artifacts of her figured world of home-school relationships. If this single story is an artifact in Princess' figured world of home-school relationships it becomes more than just a part of Princess' work. It is a part of how each actor in this figured world, which includes her colleagues and the families, develops their identities. It is important to consider potential repercussions of this particular storyline being present in Princess' figured world of home-school relationships: How could a teacher approach families openly and positively, seeing them as valuable, knowledge filled parts of their children's lives and education if they are seen through a lens of chaos (Greene, 2013)?

The significance of this research is two-fold, deepening knowledge about how teachers understand home-school relationships and considering the impact of narrow ideas about families who live in poverty. Looking at stories teachers tell can provide insight into how they come to understand the lives of the families they serve. They show how a teacher authors her own identity as a participant in home-school relationships and how stories are part of a space that families and teachers exist together in (Holland, et al., 1998). Moving forward, it is important for research to look not just at teachers, but also consider the stories of other actors within a figured world of home-school relationships. This way, voices of the support teachers and staff, families, and children can also be heard - I consider not hearing these voices a limitation of this case study. Despite this limitation, the findings of this study do contain implications for teacher educators. It is important for teacher educators to hear teachers' stories about families because they can help them better understand teachers' perspectives. Such stories can also be used as teaching tools. Caring instructors who have built strong relationships with teachers could use stories to conduct reflective self-studies that ask teachers to critically examine how they understand themselves and families. The particulars of Princess' stories ask educators to also consider who is responsible for creating chaotic images of families' lives and what happens when these types of stories are the ones told about families who live in poverty. 
Kristin Lyn Whyte

\section{References}

Anyon, J. (1980). Social class and the hidden curriculum of work. Journal of Education, 67-92.

Beatty, B. (2012). The Debate over the Young 'Disadvantaged Child': Preschool Intervention, Developmental Psychology, and Compensatory Education in the 1960s and Early 1970s. Rethinking Compensatory Education: Historical Perspectives on Race, Class, Culture, Language, and the Discourse of the 'Disadvantaged Child,' ed. Barbara Beatty, special issue, Teachers College Record, 114(6).

Adichie, C. N. (2009, July). The Danger of a Single Story. Retrieved from http://www.ted.com/talks/chimamanda_adichie_the_danger_of_a_single_story/transcript ?language $=\mathrm{en}$

Compton-Lilly, C. (2000). "Staying on Children": Challenging Stereotypes about Urban Parents. Language Arts, 77(5), 420-427.

Compton-Lilly, C. (2009). Research Directions: Listening to Families over Time: Seven Lessons Learned about Literacy in Families. Language Arts, 86(6), 449-457.

Cooper, C. W. (2009). Parent involvement, African American mothers, and the politics of care. Equity \& Excellence in Education. 42(4), 379-394. DOI: 10.1080/10665680903228389

Diamond, J. B. \& Gomez, K. (2004). African American parents educational orientations: the importance of social class and parents' perceptions of schools. Education and Urban Society. (36)4. 382-427. DOI: 10.1177/0013124504266827

Doucet, F. (2008). How African American parents understand their and teachers' roles in children's schooling and what this means for preparing pre-service teachers. Journal of Early Childhood Teacher Education, 29, 108-139.

Doucet, F. (2011). (Re) Constructing Home and School: Immigrant Parents, Agency, and the (Un) Desirability of Bridging Multiple Worlds. Teachers College Record, 113(12), 27052738.

Dyson, A. H., \& Genishi, C. (2005). On the case: Approaches to language and literacy research. Teachers College Press/NCRLL.

Greene, S. (2013). Race, community, and urban schools: Partnering with African American families. New York, NY: Teachers College Press.

Holland, D., Lachicotte, W., Skinner, D., \& Cain, C. (1998). Identity and agency in cultural worlds. Cambridge: Harvard University Press

Lareau, A. (2000). Home advantage: Social class and parental intervention in elementary education. Lanham, MD: Roman and Littlefield.

ISSN 2325-638 
"They Come from Chaos:" Considering the Power of Stories

\section{Lightfoot, S. L. (2003). The essential conversation: What parents and teachers can learn from each other. New York: Random House.}

Moll, L. C., Amanti, C., Neff, D., \& Gonzalez, N. (1992). Funds of knowledge for teaching: Using a qualitative approach to connect homes and classrooms. Theory into practice, 31(2), 132-141.

Moll, L. C. (2013). LS Vygotsky and education. New York: Routledge.

Patton, M. Q. (2002). Qualitative evaluation and research methods. SAGE Publications, Inc.

Stake, R. E. (1995). The art of case study research. Thousand Oaks, SAGE Publications, Inc.

\section{Notes}

${ }^{\text {i }}$ Participant chose her pseudonym.

ii This work was supported by the National Science Foundation under Grant 1019431.

iii It is worth noting Princess' appearance is not "princess-like." She mostly wears jeans and baggy sweatshirts, her hair is almost always pulled back tightly into a ponytail, she keeps a small silver hoop in her left eyebrow, and does not wear make-up. She also would talk about, with a glint in her eye, how she knows she's too loud and that she is working on it, which speaks to the idea that her demeanor does not reflect princess-like stereotypes.

iv I created a semi-structured interview map for Princess's interviews with topics I wanted to ensure we would talk about over time. I opened each interview with descriptive questions (Spradley, 1979). Then, instead of having an interview where I dictated the flow of the conversation, I listened to her responses and followed her lead into conversations about what influences her practices (Seidman, 2006). I used the questions I had developed and I looked to her responses to know where I should go next. Since there was no clear end to each interview, before beginning we would decide on a period of time we would talk for. After each interview I went through the interview map and took notes on the areas we had covered. Then I made any adjustments before the next interview. Sometimes adjustments would include dropping particular ques tions from the interview, adding questions based on information Princess shared, and asking for clarification on her original responses in a manner akin to member checking (Patton, 2002; Spradley, 1979).

v Princess' age \& years worked in Head Start amount is reflective of when I finished data collection.

vi According to the 2010 census, Milford had a population of 5,524 with $93.4 \%$ of people being white, $.5 \%$ African American, .6\% Native American, .9\% Asian, 3.6\% from otherraces, $1 \%$ from 2 or more races, and $8 \%$ of the population identified as Latino.

vii According to the 2010 census, Oscarburg had population of 233,309 people with $78.9 \%$ of people being white, 7.3\% African American, 7.4\% Asian American, .4\% Native American, 3.1\% from 2 or more races, 2.9\% from other races, and $6.8 \%$ of the identified as Latino.

viii She most often had me get the children's toothbrushes ready for the day.

ix Before entering academia I taught in elementary schools for 6 years and worked in childcare for 8 years.

${ }^{x}$ The findings are primarily presented in the "ethnographic present." I want to explicitly acknowledge that I struggled with deciding what tense to use and I looked to scholarly work on the ethnographic present (Hastrup, 1990; Sanjek, 1991) to help think through the implications of choosing a tense. For now I have decided that even if an event happened or statement was made in the past that writing about it in the past can give an impression that I am simply reporting what happened. I do not believe I can recreate past events or that what I experienced was the only truth. As Sanjek (1991) notes, "In my judgment, the issue comes down to distinguishing among reliability, validity and what may be called 'I-was-there' Truth. I leave such Truth to truth-seekers and truth-finders" (p. 620). I seek validity through robust methods and then allow my interpretations to guide my writing or representations. Writing primarily in the past tense can create an impression that the past stays there and I am removed from it, which does not acknowledge the role I have in creating a representation of Princess. 